\title{
Utilization of Biogas Slurry Doses from Goat Faeces with MOL (Micro Local Organisms) Banana Stem on Turi Productivity (Sesbania grandiflora) in Samosir Regency
}

\author{
S Sianturi, Nurzainah Ginting, S Umar, N D Hanafi, Yunilas. \\ Animal Production Program, Faculty of Agriculture, University of north sumatera, \\ Medan 20155 \\ E-mail: nurzainah@usu.ac.id
}

\begin{abstract}
This study aims to investigate the effect of utilization of biogas slurry doses with MOL (Micro Local Organisms) Banana Stumps on Turi Productivity (Sesbania grandiflora). This research was conducted in Samosir Regency, North Sumatra starting from May to September 2018. The design used in this study was a completely randomized design with 4 treatment levels of 5 replications, the data analysis used was Duncan's Advanced Test. Treatment with various doses of biogas slurry fertilizer by input of goat faeces which is fermented with MOL (Micro Local Organism), 2 liter MOL banana stem. P0 $=0, \mathrm{P} 1=20, \mathrm{P} 2$ $=40, \mathrm{P} 3=60(\mathrm{t} / \mathrm{h} / \mathrm{yr})$. The variables observed were plant height, stem diameter, number of stems, number of leaves, and leaf width. The results of the study showed that the fermentation of goat's bio-gas slurry fertilizer with various doses of fertilizing gave a significant influence on the parameters of the study, namely plant height, number of stems, number of leaves, and stem diameter. The best response due to fertilization is with a dose of $60 \mathrm{t} / \mathrm{h} / \mathrm{yr}$.
\end{abstract}

\section{Introduction}

Livestock and plantation businesses must produce waste, in addition to the main results. Livestock waste is waste from a livestock business, such as livestock raising, processing of livestock products and slaughterhouses.

One type of livestock that is kept by many people in Samosir Regency is goats. Goats in Samosir Regency reached 9,700 in 2015. The population of these goats is spread in nine sub-districts in Samosir where more are in Pangunguran, Simanindo, Palipi, and Ronggur Nihuta Districts. Samosir goat is a genuine samosir goat which based on its history is maintained by local residents from generation to generation on Samosir Island. The Samosir goat, better known as the panorusan goat, was originally used for offering ceremonies at the religious ceremony of one of the aninism faiths (Parmalim) by local residents. The goat needed must be white, because it relates to Batak ethnic customs making this goat a high investment because of its high price.

Goat faeces waste is organic material which if not managed properly can cause environmental pollution both biologically, chemically and physically. Improper management of livestock waste can cause pollution of water, soil, and air resulting in a decrease in environmental quality, the quality of life of farmers and their livestock and can lead to social conflict. Well-managed waste management in addition to preventing environmental pollution also provides economic value to livestock business. 
The need for forage is one of the necessary and large benefits for life and the survival of livestock populations. One of the main obstacles in increasing livestock productivity in developing countries is the quality and quantity of fluctuating feed, especially in the dry season.

Turi plants belong to the class of legumes that have good nutrients for animal feed ingredients because of their high protein content and good protein quality. Besides that it is rich in vitamin A and as a source of $\mathrm{Ca}$ (Calcium) and $\mathrm{P}$ (Phosphorus). The giji content is $36.3 \mathrm{~g}$ protein, $7.5 \mathrm{~g}$ fat, $47.1 \mathrm{~g}$ carbohydrate, $1684 \mathrm{mg} \mathrm{Ca}, 258 \mathrm{mg}$ phosphorus (P), $21 \mathrm{mg} \mathrm{Na}, 2.005 \mathrm{mg} \mathrm{K}, 25.67 \mathrm{mg}$ b-carotene, 1.00 $\mathrm{mg}$ thiamin , 1.04 riboflavin, $9.17 \mathrm{mg}$ niacin and vitamins (A, B1 and C) Duke, 1983 [1].

The use of bio-gas slurry as fertilizer can provide almost the same benefits as compost. The rest of this biogas output has undergone anaerobic fermentation - the average input of livestock feces is 30 days so that weed seeds that are included in the faeces are confirmed dead and the faeces has decomposed more simply and the nutrients can be absorbed by plants. Slurry as an organic fertilizer includes complete compound fertilizer because its nutrient content is more than one element and contains macro and micro elements Suzuki et al. 2001 [2]. Showed that bio-gas slurries were rich in macro elements $\mathrm{N}, \mathrm{P}$, and $\mathrm{K}$ as well as micro elements such as $\mathrm{Ca}, \mathrm{Mg}, \mathrm{Fe}, \mathrm{Mn}, \mathrm{Cu}$, and $\mathrm{Zn}$.

Based on the description above, the researcher was interested in conducting research on the utilization of bio-gas slurries with input of goat faeces with various doses of MOL (Micro Local organisms) Banana Bonggol on Turi (Sesbania grandiflora) productivity as animal feed ingredients.

\section{Materials and Methods}

The study was conducted in the Parlondut Village, Pangururan Subdistrict, Samosir Regency, North Sumatra. This study lasted for 5 months with 2 weeks of land preparation carried out from May to September 2018.

The material used is the seed of Turi leguminosa (Sesbania grandiflora) from seeds to age 45 days. Plots measuring $1.5 \times 1.5 \mathrm{~m}$ as many as 20 plots, goat faeces, molasses / brown sugar, banana stem as an ingredient for making organic bioactivator. Water for watering plants at the time of the study._The tools used are hoes to clean the land, loose for watering plants, shoves to measure the diameter of the stem, meter or cloth measuring instruments to measure plant height, data books, pens, calculators, plastic straps and cutter knives.

Biogas slurry was treated with bioactivator which made from banana stem.

The experimental design used was a completely randomized design (CRD). The treatment that will be used in this study are:

$\mathrm{P} 0=$ without biogas slurry (control)

$\mathrm{P} 1$ = biogas slurry with a dose of $166 \mathrm{~g} / \mathrm{plot}$ (20 tons / ha / year)

$\mathrm{P} 2=$ biogas slurry with a dose of $333 \mathrm{~g} / \mathrm{plot}$ (40 tons / ha / year)

P3 = biogas slurry with a dose of $499 \mathrm{~g} /$ plot (60 tons / ha / year)

Plot Size $=1.5$ x 1.5 meters, 1 Plot $=1$ Turi Plant, Spacing between plants: 1 x 1 meter

The data obtained will be analyzed, and if the treatment is significantly different $(F \geq 0.5)$ or very real $(\mathrm{F} \geq 0.1)$ then it is further tested using the Duncan test.

\section{Plant height}

Measurement of plant height using a measuring tape, from the base of the plant above the ground to the end of the plant canopy.

2. Stem Diameter

Plants were counted for the number of leaves growing in each treatment

3. Number of Stalks

Plants were counted for the number of stems that grew in each treatment.

4. Number of Leaves

Stem diameter is measured before harvesting using the calipers. Measurement of stem diameter is done $10 \mathrm{~cm}$ above the ground by clamping the stem of the plant with a caliper. Then the measuring lever is shifted until it doesn't move anymore and you see the number on the sliding runway. 


\section{Leaf Width}

Plants are measured in width by using a meter or ruler. Measurements were made on the widest leaves in each treatment.

\section{Results and Discussion}

\subsection{Plant Height $(\mathrm{cm})$}

The results of the research on the utilization of liquid fertilizer from goat faeces slurry against the height of Sesbania grandiflora plants can be seen in the following Table 1.

Table 1. Average plant height $(\mathrm{cm})$ Sesbania grandiflora

\begin{tabular}{crrrrrr}
\hline Treatment & \multicolumn{5}{c}{ Deuteronomy } & \multirow{2}{*}{ Average } \\
\cline { 2 - 6 } & $\mathrm{U} 1$ & $\mathrm{U} 2$ & $\mathrm{U} 3$ & $\mathrm{U} 4$ & $\mathrm{U} 5$ & \\
\hline $\mathrm{P}_{0}$ & 53 & 70 & 87 & 41 & 59 & $62^{\mathrm{a}}$ \\
$\mathrm{P}_{1}$ & 64 & 101 & 70 & 92 & 62 & $77,8^{\mathrm{ab}}$ \\
$\mathrm{P}_{2}$ & 88 & 104 & 79 & 110 & 80 & $92,2^{\mathrm{b}}$ \\
$\mathrm{P}_{3}$ & 85 & 106 & 75 & 117 & 91 & $94,8^{\mathrm{b}}$ \\
\hline
\end{tabular}

Description: Different superscriptions in the same row or column show the real number in the Duncan test $(\mathrm{p}<0.05)$

In Table 1 we can see that plant height (sesbania grandiflora) increased due to the administration of P1 (biogas slurry with a dose of $166 \mathrm{~g} /$ plot), P2 (biogas slurry with a dose of $333 \mathrm{~g} / \mathrm{plot}$ ), P3 (biogas slurry with a dose of $499 \mathrm{~g} /$ plot), compared to P0 (control). This is due to the provision of biogas slurry which automatically increases the growth of forage better than forage without fertilizer (P0). This is in accordance with the statement of Lingga and Marsono 2008 [3]. stating that the provision of organic fertilizers can improve soil structure, increase nutrient absorption of soil by water, increase living conditions in the soil, and as a source of food for plants.

The results of the study based on the Duncan test showed that the administration of bio-gas slurry from goat faecal fermentation had a significant effect on the height of turi legume plants (Sesbania grandiflora). There is a significant difference between P0 and P1, P2, and P3, while between P1, P2 and P3 do not show a significant difference. Considering the efficient use of goat faeces bio slurry doses for better turi productivity, P1 can represent a good dose of bio-gas slurry to be applied to Turi plants (Sesbania grandiflora).

\subsection{Stem Diameter (mm)}

The results of the research on the utilization of liquid fertilizer from goat faeces slurry against the stem diameter of the Sesbania grandiflora plant can be seen in the following Table.

Table 2. Average stem diameter ( $\mathrm{mm})$ Sesbania grandiflora

\begin{tabular}{ccccccr}
\hline Treatment & \multicolumn{5}{c}{ Deuteronomy } & \multirow{2}{*}{ Average } \\
\cline { 2 - 6 } & $\mathrm{U} 1$ & $\mathrm{U} 2$ & $\mathrm{U} 3$ & $\mathrm{U} 4$ & $\mathrm{U} 5$ & \\
\hline $\mathrm{P}_{0}$ & 12 & 19 & 19 & 10 & 13 & $14,6^{\mathrm{a}}$ \\
$\mathrm{P}_{1}$ & 12 & 19 & 15 & 22 & 20 & $18,2^{\mathrm{ab}}$ \\
$\mathrm{P}_{2}$ & 19 & 20 & 22 & 22 & 17 & $20^{\mathrm{b}}$ \\
$\mathrm{P}_{3}$ & 21 & 21 & 22 & 22 & 23 & $21,8^{\mathrm{b}}$ \\
\hline
\end{tabular}


Description: Different superscriptions in the same row or column show the real number in the Duncan test $(\mathrm{p}<0.05)$

The results of the study based on the Duncan test showed that the administration of biogas slurry from goat faecal fermentation had a significant effect on the stem diameter of turi legume plants (Sesbania grandiflora). There is a significant difference between P0 and P1, P2, and P3, while between P1, P2 and $\mathrm{P} 3$ do not show a significant difference. Considering the efficient use of goat faeces bio slurry doses for better turi productivity, P1 can represent a good dose of bio-gas slurry to be applied to Turi plants (Sesbania grandiflora).

In further testing using the Duncan test it can be seen that fertilization has a significant effect on turi plants. Where the highest plant diameter average is found in P3 of 21.8 and the lowest average at P0 is 14.6. This is related to nutrients given by liquid organic fertilizer, goat faeces, which can change the physical properties of the soil, especially in the soil structure. Increased value of vegetative characters such as plant height and plant stem diameter caused by the role of elements of nitrogen. The main role of nitrogen for plants is to stimulate overall growth, especially the stems, branches, and leaves of Hardjowigeno 2007 [4]. Plants need nutrients that are suitable for their needs in the process of growth and development.

\subsection{Number of Stalks}

The results of the research on the utilization of liquid fertilizer of goat faeces slurry against the number of branches in Sesbania grandiflora plants can be seen in the following Table.

Table 3. Average number of branches of Sesbania grandiflora

\begin{tabular}{crrrrrrr}
\hline Treatment & \multicolumn{9}{c}{ Deuteronomy } & \multirow{2}{*}{ Average } \\
\cline { 2 - 6 } & $\mathrm{U} 1$ & $\mathrm{U} 2$ & $\mathrm{U} 3$ & $\mathrm{U} 4$ & $\mathrm{U} 5$ & \\
\hline $\mathrm{P}_{0}$ & 50 & 47 & 57 & 30 & 48 & $46,4^{\mathrm{a}}$ \\
$\mathrm{P}_{1}$ & 41 & 64 & 52 & 61 & 62 & $56^{\mathrm{ab}}$ \\
$\mathrm{P}_{2}$ & 50 & 79 & 67 & 88 & 65 & $69,8^{\mathrm{bc}}$ \\
$\mathrm{P}_{3}$ & 61 & 80 & 59 & 92 & 74 & $73,2^{\mathrm{c}}$ \\
\hline
\end{tabular}

Description: Different superscriptions in the same row or column show the real number in the Duncan test $(\mathrm{p}<0.05)$

The results of variance showed that the administration of bio-gas slurry from goat faeces fermented significantly affected the number of branches of Turi plants (sesbania grandiflora), increased development due to the administration of P1 (biogas slurry with a dose of $166 \mathrm{~g} / \mathrm{plot}$ ), P2 (biogas slurry with a dose of $333 \mathrm{~g} /$ plot), P3 (biogas slurry with a dose of $499 \mathrm{~g} /$ plot), compared to P0 (control). This is due to the nutrient content of the biogas slurry, namely elements $\mathrm{N}, \mathrm{P}, \mathrm{K}$, which automatically increases the growth of forage better than forage without fertilizer (P0). The main role of nitrogen for plants is to stimulate overall growth, especially the stems, branches, and leaves of Hardjowigeno 2007. Plants need nutrients that are suitable for their needs in the process of growth and development.

In further testing using the Duncan test it can be seen that fertilization has a significant effect on the number of branches of turi plants. Where the highest average number of branches is found in P3 of 73.2 and the lowest average at $\mathrm{P} 0$ is 46.4. The main role of nitrogen for plants is to stimulate overall growth, especially the number of branches. This is consistent with the statement of Hardjowigeno 2007 which states that the main role of nitrogen for plants is to stimulate overall growth, especially the number of branches. 


\subsection{Number of Leaves}

The results of the research on the utilization of liquid fertilizer of goat faeces slur against the number of leaves in Sesbania grandiflora plants can be seen in the following Table.

Table 4. Average number of leaves (strands) of Sesbania grandiflora

\begin{tabular}{cccrrrr}
\hline Treatment & \multicolumn{9}{c}{ Deuteronomy } & \multirow{2}{*}{ Average } \\
\cline { 2 - 5 } & U1 & U2 & U3 & U4 & U5 & \\
\hline $\mathrm{P}_{0}$ & 1272 & 1548 & 1952 & 582 & 1136 & $1298^{\mathrm{a}}$ \\
$\mathrm{P}_{1}$ & 1052 & 2014 & 1100 & 2150 & 1986 & $1660,4^{\mathrm{ab}}$ \\
$\mathrm{P}_{2}$ & 1930 & 2132 & 1912 & 2056 & 2254 & $2056,8^{\mathrm{bc}}$ \\
$\mathrm{P}_{3}$ & 2236 & 2200 & 2312 & 2896 & 2134 & $2355,6^{\mathrm{c}}$ \\
\hline
\end{tabular}

Description: Different superscriptions in the same row or column show the real number in the Duncan test $(\mathrm{p}<0.05)$

Based on the research that has been done, it can be seen that the administration of organic goat fertilizer fermented in Turi legiuminosa (Sesbania grandiflora) resulted in the growth in the number of leaves of legium plants which increased compared to the treatment without the administration of fermented organic fertilizer (P0). This supports plant growth because the leaves are one of the most important plant organs of plants that function as a place for photosynthesis. In accordance with statement Syukron's 2000 [5]. that plant growth is in line with the development of the number of leaves. Leaves are the most important producer of photosynthate organs, increasing the number of leaves will give more photosynthate results. Furthermore Novizan 2002 states that the lack of nutrients in the soil can be added by giving fertilizer, so that plant growth becomes more optimal. In further testing using the Duncan test it can be seen that fertilization has a significant effect on the number of leaves of turi plants. Where the highest average number of leaf plants is found in P3 of 2355.6 and the lowest average at P0 is 1298 This is in accordance with the study of Bara and Chozin 2009 [6]. which states that Giving organic goat fertilizer has a significant effect on plant height, number of leaves, and diameter stem. Increasing the manure dosage is directly proportional to the increase in plant height and number of leaves. The larger the dose of manure, the higher the plant height and number of leaves.

\subsection{Leaf Width}

The results of the research on the utilization of liquid fertilizer of goat faeces sludge against leaf width in Sesbania grandiflora plants can be seen in the following Table.

Table 5. Average leaf width $(\mathrm{cm})$ Sesbania grandiflora

\begin{tabular}{ccccccr}
\hline Treatment & \multicolumn{3}{c}{ Deuteronomy } & \multicolumn{2}{c}{ Average } \\
\cline { 2 - 6 } & $\mathrm{U} 1$ & $\mathrm{U} 2$ & $\mathrm{U} 3$ & $\mathrm{U} 4$ & $\mathrm{U} 5$ & \\
\hline $\mathrm{P}_{0}$ & 1,6 & 1,6 & 1,3 & 1,3 & 1,6 & $1,48^{\mathrm{a}}$ \\
$\mathrm{P}_{1}$ & 1,4 & 1,4 & 1,5 & 1,5 & 1,8 & $1,52^{\text {ab }}$ \\
$\mathrm{P}_{2}$ & 1,5 & 1,7 & 1,9 & 2 & 1,8 & $1,76^{\mathrm{b}}$ \\
$\mathrm{P}_{3}$ & 1,5 & 1,7 & 1,9 & 2 & 1,8 & $1,78^{\mathrm{b}}$ \\
\hline
\end{tabular}


Description: Different superscriptions in the same row or column show the real number in the Duncan test $(\mathrm{p}<0.05)$

In Table 5 we can see that Leaf Width (sesbania grandiflora) increases due to the administration of P1 (biogas slurry with a dose of $166 \mathrm{~g} /$ plot), P2 (biogas slurry with a dose of $333 \mathrm{~g} /$ plot), P3 (biogas slurry with a dose of $499 \mathrm{~g} / \mathrm{plot}$ ), compared to P0 (control). This is due to the provision of biogas slurry which automatically increases the growth of forage better than forage without fertilizer application. This is in accordance with Rizwan 2008 [7]. statement, which states that goat manure has the property of improving soil aeration, increasing the ability of soil to retain nutrients, increasing the capacity to hold water, increasing soil buffering, an energy source for soil microorganisms and as a source of nutrients. Goat manure contains $\mathrm{N}$ which can encourage organs related to photosynthesis, namely leaves.

The results of the study based on the Duncan test showed that the administration of biogas slurry from goat faecal fermentation had a significant effect on the leaf width of the thorn leguminous plants (Sesbania grandiflora). There is a significant difference between P0 and P1, P2, and P3, while between P1, P2 and P3 do not show a significant difference. Considering the efficient use of goat faeces bioslurry doses for better tury productivity, P1 can represent a good dose of bio-gas slurry to be applied to Turi plants (Sesbania grandiflora). This is due to the provision of biogas slurry which has nutrients N, $\mathrm{P}, \mathrm{K}$ which can accelerate plant growth. This is in accordance with Odedina's statement 2011 [8]. which states that goat manure has a significant effect on plant fresh weight, plant dry weight, leaf area, pod fresh weight, dry weight, leaf number, and stem diameter. This is because the administration of goat manure can improve the physical, chemical and biological properties of the soil.

\section{Conclusion}

1. The higher use of bio-gas slurry dosage from faeces goats on Sesbania grandiflora plants can increase the production of plant height, number of leaves, number of branches, stem diameter and leaf width in Sesbania grandiflora plants.

2. Giving P1 (biogas slurry with a dose of $166 \mathrm{~g} / \mathrm{plot}$ ), P2 (biogas slurry with a dose of $333 \mathrm{~g} / \mathrm{plot}$ ), P3 (biogas slurry with a dose of $499 \mathrm{~g} / \mathrm{plot}$ ), causing production of plant height, number of leaves, the number of branches, stem diameter and leaf width are higher when compared to P0 (control).

\section{References}

[1] Duke J.A.,1983. Handbook of energy Crops (Unpublished) hord.purdue.edu/duke.30 Agustus 2009.

[2] Suzuki, K., Amitani, R., and Animmi. 2001. Serum Eosinophil Cationic Protein as a Marker of Eosinophilic Inflamation in Astma. England.

[3] Lingga.P dan Marsono. 2006.Petunjuk Penggunaan pupuk. Jakarta : Penebar Swadaya.

[4] Hardjowigeno, S., 2007. Ilmu Tanah. Mediyatama Sarana Perkasa, Jakarta.

[5] Syukron. 2000. Pengaruh Perlakuan Pupuk Hijau Terhadap Bibit Setek Cabang Buah Tanaman Lada (Piper nigrum Linn.). Skripsi. Bogor: Fakultas Pertanian IPB.

[6] Bara, A. and M. A. Chozin. 2009. Pengaruh Pemberian Pupuk Kandang. Dalam Kumpulan Makalah Seminar Hasil Penelitian Departemen Agronomi dan Holtikultura Fakultas Pertanian Institut Pertanian Bogor. Bogor.

[7] Rizwan. 2008. Panduan Lengkap Budidaya Kakao. Agromedia Pustaka, Jakarta.

[8] Odedina. 2011. Comparison of The Effectiveness of Composting for The Biological Stabilization of Cattle Manure. Chemosphere 72. 